Article

\title{
On Convergence, Ongoing Language Change, and Crosslinguistic Influence in Direct Object Expression in Catalan-Spanish Bilingualism
}

\author{
Silvia Perpiñán \\ Hispanic Studies \& Program of Linguistics, Department of Modern Languages and Literatures, \\ The University of Western Ontario, Arts \& Humanities Building, 3R12B, London, ON N6A 3K7, Canada; \\ sperpina@uwo.ca
}

Received: 14 December 2017; Accepted: 19 April 2018; Published: 27 April 2018

\begin{abstract}
The present study explores two morphological differences in direct object expression between Spanish and Catalan: Differential Object Marking (DOM), and the accusative clitics $e l / l /$ vs. ho /u/. Both phenomena are regulated by semantic features, such as animacy and specificity/definiteness. The study experimentally tested 57 Catalan-Spanish bilinguals with different degrees of language dominance in their comprehension and production of these Catalan constructions in order to explore the degree of structural convergence. The results show that with respect to DOM, bilinguals systematically accept ample optionality, creating a new language variety, the bilingual variety, with properties similar and different from both Spanish and Catalan. With respect to the accusative clitics, a certain degree of functional interference in the grammar of Spanish-dominant bilinguals is found. These results illustrate, on the one hand, structural convergence in DOM, culminating in an internal language change accelerated by language contact, and, on the other hand, incipient language transfer from the dominant language in the expression of accusative clitics.
\end{abstract}

Keywords: accusative clitics; DOM; language convergence; Catalan; Spanish; definiteness; bilingualism; language change; crosslinguistic influence

\section{Introduction}

Catalan and Spanish languages have been in contact for centuries, but the linguistic contact has never been as intense as in the last half of the 20th century-beginning of 21st century, where, as a result of large waves of migration as well as linguistic and educational policies, practically everybody born and raised in Catalonia in the last 40 years has become bilingual to some degree. This has created a bilingualism continuum (Perpiñán 2017) that ranges from strong dominance in one of the languages and passive use of the other, to a more balanced bilingualism; in this gradation of bilingualism, I also include certain types of second language acquisition, particularly child L2 acquisition. Catalonia has around 7 million inhabitants, of whom only 31\% declare to have Catalan as their first language, whereas $55 \%$ of Catalans have Spanish as their first language. However, $65 \%$ of the people born in Catalonia use both languages habitually (Idescat 2013), so a considerable percentage of the population may use their second language as their habitual language. This intense and extensive contact in both society and in the bilingual mind raises the question of linguistic influence and/or structural convergence between Catalan and Spanish, and the eventuality of language change. The goal of the present paper is to examine functional interference/convergence in bilingual grammar related to grammatical complexity and its possible outcomes, such as simplification, convergence, and potential language change.

This study takes into account intralinguistic factors as well as extralinguistic ones in order to characterize the different varieties of Catalan that have emerged in this bilingual context. In particular, 
it explores the role of language dominance, measured as a compound variable that averages language use, language preference and identity, family linguistic background and onset of bilingualism, and the robustness or vulnerability of certain grammatical domains in the linguistic competence of bilinguals. Some of the questions that arise in the study of acquisition in a stable bilingual community relate to the role of the language used by the majority of individuals versus that used by the minority (Gathercole and Thomas 2009), and the crosslinguistic influences or possible changes that one or both languages may undergo as a result of prolonged contact.

From one perspective, Trudgill (1989) proposed that language contact situations produce erosion or simplification of the internal development of languages, resulting in loss of morphology, and increases in regularity, analyticity, transparency, and redundancy; this has been mostly attested by the development of pidgin languages, a special circumstance in which a language is learned by non-native speakers. McWhorter (2007) has applied controversial metrics of complexity in the study of languages which have been massively learned by second language learners, such as English or Mandarin, and has concluded that all of these languages have suffered some sort of simplification as a result of incomplete learning by non-native speakers. Under this construct of complexity, which takes into account overspecification, structural elaboration and irregularity, a language that contains Differential Object Marking (DOM) in animate, specific direct objects is more complex (more overspecified and more elaborated) than grammar that does not mark DOM.

Another possible outcome of this intense contact is convergence. Silva-Corvalán (1986, 1994, 2008) reflected on the limits of syntactic convergence by proposing that bilingual speakers do not modify the abstract syntactic structure of the receding language; that is, the transfer of features from one language to another does not involve syntax, but it can involve lexicon and pragmatics. These observations resemble those proposed by the interface hypothesis (Sorace and Filiaci 2006; Sorace 2011), which sustains that bilingual speakers, particularly near-native speakers, L1 attritors, child bilinguals and heritage speakers, present optionality and/or protracted indeterminacy in structures involving an interface between syntax and other cognitive domains, but that structures that only require syntactic computations remain fairly stable. Continuing with the analysis at the individual level, and using second language acquisition models, it has been proposed that L2 learners are not able to acquire inflectional morphology or functional features that do not exist in L1 speakers (Hawkins and Chan 1997). Other authors believe that semantics are universal and that the only difficulty in the acquisition process is in the reassembly of semantic features into functional morphology (Lardiere 2008; Slabakova 2009. Building on this idea, Sánchez $(2003,2015)$ proposed the concepts of functional interference and functional convergence-there is functional interference when "the activation of functional features in one language, triggered by input in the other language, generates syntactic change in the bilingual grammars" (Sánchez 2003, p. 13). This happens when language A has functional features that are (I) not present in language B; (II) associated with a different functional category in language B; (III) bundled with other functional features in language B; or (IV) any combination of (I), (II), and (III). Functional convergence, on the other hand, is "the specification of a common set of features shared by the equivalent functional categories in the two languages spoken by a bilingual" (Sánchez 2003, p. 15). The main difference between the two processes is the result-convergence produces a new specification of features in the two languages spoken by a bilingual, whereas in functional interference, the set of features and functional categories from language $A$ are adopted in language $B$.

In this study, we draw concepts from both related frameworks, language contact and second language acquisition, to better investigate the expression of Catalan direct objects and their semantic properties in bilingualism/language contact situations. Our general research question is whether the expression of direct objects in Catalan is affected by the intense contact with Spanish. For instance, we question whether Spanish-dominant early bilinguals are able to fully master functional categories and their semantic distribution in their non-dominant language, Catalan. We also question whether simplification, optionality, or indeterminacy takes place necessarily in a language contact situation, 
specifically regarding the expression of direct objects in the Catalan spoken by different types of bilinguals. We focus on the feature definiteness/specificity and how it is expressed in Catalan direct objects by speakers whose dominant/native language is Spanish, Catalan, or both. These are questions that are usually investigated separately, either at the society level in the field of contact linguistics, or at the individual level in the field of second language acquisition. However, we believe that our understanding about bilingualism will benefit from a more holistic view in which the study of the bilingual speakers and their grammar contributes to the characterization of the bilingual variety spoken in the society and vice versa. Taking into account these two approaches, one can evaluate possible ongoing language change resulting from language contact and/or incomplete acquisition. For instance, Silva-Corvalán (1994) proposed that language-contact situations accelerate diachronic changes that are already taking place in monolingual varieties, such as the extension of estar in U.S. Spanish. A further assumption we make is that the individual forms of grammar used by different types of bilinguals represents the several linguistic varieties existent in the community, and that these varieties, in turn, can represent the different stages of a possible linguistic change.

\section{The Linguistic Phenomena}

In this study, we investigate two linguistic phenomena in relation to the expression of direct objects in Catalan that considerably differ from Spanish: the presence/absence of Differential Object Marking (DOM), and the clitization of the third person masculine singular object. The behavior of these two phenomena is determined, among other features, by the specificity/definiteness of the object. This study is a first approximation of the statuses of these two Catalan language phenomena in bilingualism.

\subsection{Differential Object Marking}

Differential Object Marking is the overt morphology that identifies direct objects in many unrelated languages of the world; in Romance languages, DOM is an innovation from Latin, that was created after the case system was lost and was probably present already in Vulgar Latin (Meier 1947). It is systematically found in Spanish and Romanian, and more restrictively in Catalan, Sardinian, and Portuguese (Salvador and Saldanya 1993). According to Aissen (2003), the distribution of DOM is primarily determined by two parameters: animacy and definiteness/specificity. In Spanish, animate and specific (definite) direct objects are marked with the preposition $a$, whereas in Standard Catalan, ${ }^{1}$ direct objects do not present any special identifying mark in these contexts:

1. [+animate, +specific]
a. En Joan buscava
(*a) la Maria ahir a la tarda
Catalan
b. Juan buscaba *(a) María ayer por la tarde
'John was looking for Mary yesterday evening.'
Spanish

However, in Catalan, strong personal pronouns (2a) and some indefinite pronouns (2b) require or accept the preposition $a$ (Bel 2002):

1 An anonymous reviewer questioned the idea of "Standard Catalan" because there are virtually no monolingual varieties of Catalan, and s/he considers that the standard variety takes bilingual Catalan into account. This is not the case, as "Standard" or "Normative" Catalan is an ideal and unmarked variety, geographically speaking, created to unify and standardize the language, and serves as a reference model for the media, school, and administrative contexts. It was initially proposed by Fabra and seconded by the Institut d'Estudis Catalan (IEC) at the beginning of the XXth century (Segarra 1987). 


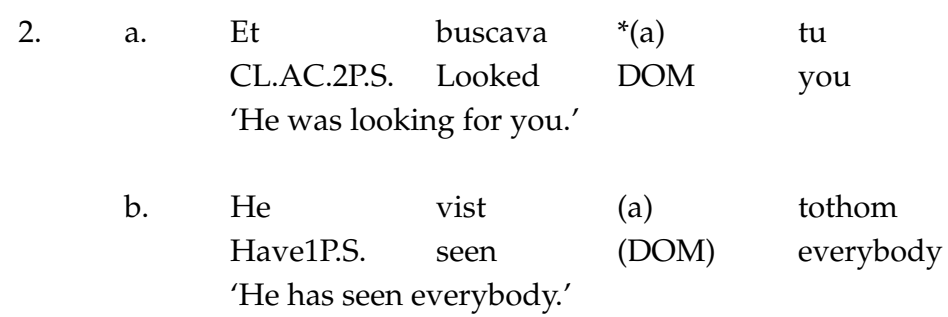

This preposition also appears in Catalan topicalized animate objects, in clitic left or right dislocations, which is a recommended use of DOM by Catalan grammarians, such as Solà (1994) and Ruaix i Vinyet (1994):
3. (A)

la Maria
ahir a la tarda
yesterday in the evenning
la buscava en Joan
(DOM) the Maria yesterday in the evenning CL.3p.FEM.AC searched the Joan
'It is Maria who Joan was looking for yesterday evening.'

This preposition is more widespread in Balearic Catalan (Escandell-Vidal 2009), which has been present since the XVII century and is used also in non-animate contexts:
4. Colliu-les,
"Harvest them, the pears that are already ripe."
que ja són madures
that already are ripe
(De Borja Moll 1968)

Its use in non-topicalized constructions is accepted in cases of ambiguity (5) by the conservative Fabra normative (Fabra 1918), which also states the need for a preposition with strong personal pronouns. This normative does not accept other uses of DOM in Catalan.
5. $\quad \mathrm{El}$
perseguia
com el gat
as the cat
(DOM)
la rata
CL.AC.3P.S. chased as the cat (DOM) the rat

'S/He would chase him as the cat to the rat.'

Nonetheless, this preposition is widely extended in spoken and colloquial registers in Catalan (Sancho Cremades 2002), to the extent that Hualde (1992) stated that "for most speakers, in the spoken language, all human direct objects are marked by the preposition $a^{\prime \prime}$ (p. 86). The origin and extension of this preposition have been largely debated, as to whether it is the result of the internal evolution of Catalan or the influence from Spanish. Its use in dislocated contexts or parallel constructions occurred in Medieval Catalan (Pereda i Parramon 1986, 1987), and thus it was never considered to be the result of an influence from Spanish but rather, an internal Catalan process (Rohlfs 1971). Other more innovative uses might have been influenced by Spanish, so its actual widespread use could be the result of internal as well as external factors (Salvador and Saldanya 1993). We hope that our study, although it was not originally conceived with this purpose, helps to shed some light into these issues.

In Spanish, DOM is regulated by a combination of semantic features, such as definiteness, specificity, aspect, topicality, agentivity, and affectenedness (Torrego 1998). It is obligatory with [+animate] and [+specific] objects, and variable with inanimate and non-specific indefinite objects (López 2012), animacy being the dominant trigger for DOM (Leonetti 2004). However, there are exceptions to this rule and a certain vagueness in the criteria that regulates the use of DOM, not only in Spanish but also in other languages with DOM (Aissen 2003). Syntactically speaking, it is proposed that DOM objects project an additional higher functional projection outside the VP (Rodríguez-Mondoñedo 2008; Torrego 1998), and that DOM objects must move outside the VP to either be case-marked in the specifier $(v \mathrm{P})$ or to mark specificity. Thus, if Catalan does not project this functional projection, the role of Spanish-dominant bilinguals is to unlearn, suppress, or unspecify this category when using Catalan. Finally, we need to add that the preposition $a$ is used both in Catalan and Spanish as the dative marker, and that it is obligatory in both languages in dative contexts. According to Salvador and Salvador and Saldanya (1993), the isomorphism between DOM and prototypical indirect objects and similarities in form and function may contribute to the expansion of $a$ in direct object (DO) contexts in Catalan as well. 


\subsection{Clitization of Direct Objects}

Catalan pronominalizes singular direct objects with three possible types of clitic pronouns: (I) the clitic represented by the morpheme, $/ 1 /$, for definite accusative forms in the third person, (see Table 1 for its singular forms); (II) the neutral clitic, ho /u/; and (III) the partitive, en/n/. Spanish, on the other hand, has the single form lo that subsumes all uses for masculine, singular objects.

Table 1. Catalan accusative definite clitic, singular forms.

\begin{tabular}{ccc}
\hline & Masculine & Feminine \\
\hline Proclisis (before the verb) & $e l$ & $l a$ \\
Reduced form & $l^{\prime}$ & $l^{\prime}$ \\
\hline Enclisis (after the verb) & $-l o$ & $-l a$ \\
Reduced form & $\prime$ & $' l$ \\
\hline
\end{tabular}

(I) The clitic, $/ 1 /$, agrees in gender and number with the object and is restricted to definite objects, animate (6a) or inanimate (6b). This pronoun varies according to its position (proclitic or enclitic), and the phonological environment. With finite verbal forms, clitics need to be in proclisis $(6 \mathrm{a}, 6 \mathrm{~b})$; with imperatives, the clitic is always in its enclitic form (6c). With infinitives and gerunds of periphrastic tenses (restructuring contexts), the pronoun can appear in either form (6d, $6 \mathrm{~d}^{\prime}$; optional clitic climbing).

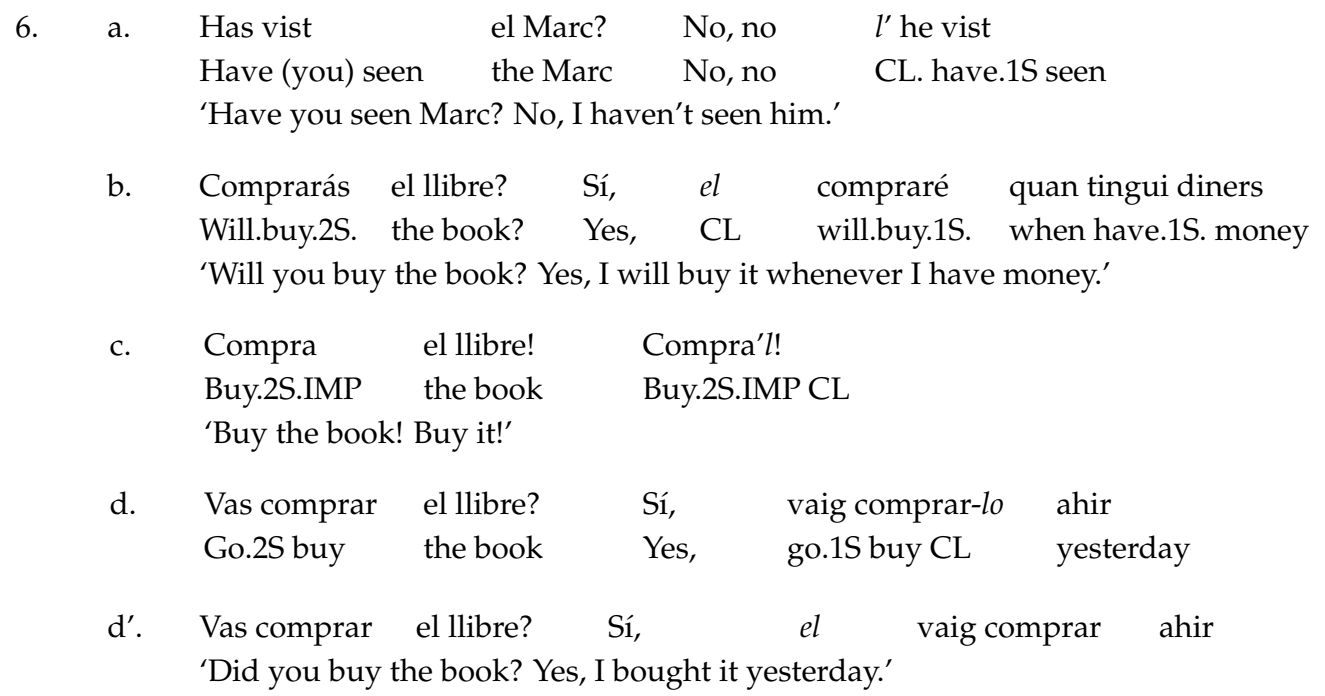

(II) The invariable ho is used to refer to subordinate clauses (7a) or to the neuter determinants/pronouns, això $\mathrm{o}$ allò, which refer to 'this thing', 'that thing' (7b).

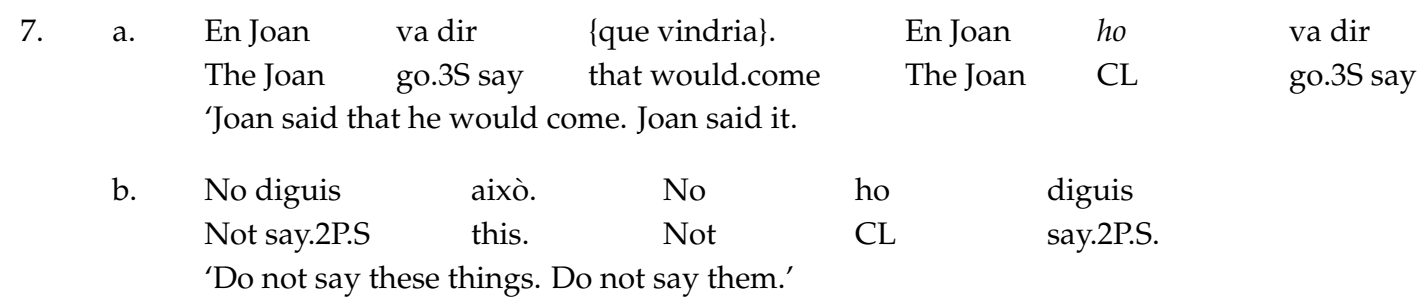

Additionally, ho also pronominalizes attributive complements that are introduced with copulative or semicopulative verbs, such as in (8a). However, according to Fabra (1956) and to Roca (1992), when the nominal predicate is a definite NP, then the [+def] clitic appears (8b): 


\begin{tabular}{|c|c|c|c|c|c|c|}
\hline \multirow[t]{2}{*}{8.} & $\begin{array}{l}\text { En Pere } \\
\text { The Pere }\end{array}$ & $\begin{array}{l}\text { és mestre. } \\
\text { is teacher. }\end{array}$ & $\begin{array}{l}\text { En Pere } \\
\text { The Pere }\end{array}$ & $\begin{array}{l}\text { ho } \\
\mathrm{CL}\end{array}$ & $\begin{array}{l}\text { és } \\
\text { is }\end{array}$ & (Fabra 1956) \\
\hline & \multicolumn{6}{|c|}{ 'Pere is a teacher. He is so.' } \\
\hline b. & $\begin{array}{l}\text { En Pere } \\
\text { The Pere }\end{array}$ & $\begin{array}{l}\text { és el mestr } \\
\text { is the teacl }\end{array}$ & $\begin{array}{l}\text { l'Espot. } \\
\text { of Espot. }\end{array}$ & $\begin{array}{l}\text { En Pere } \\
\text { The Pere }\end{array}$ & $\begin{array}{l}\text { l'és } \\
\mathrm{CL} \text { is }\end{array}$ & (Fabra 1956) \\
\hline
\end{tabular}

Crucially, the clitic ho is not available for definite masculine objects:

\begin{tabular}{|c|c|c|c|c|}
\hline $\begin{array}{l}\text { Qui } \\
\text { Who }\end{array}$ & $\begin{array}{l}\text { va rebre } \\
\text { go. } 3 S \text { receive }\end{array}$ & $\begin{array}{l}\text { el regal? } \\
\text { the present? }\end{array}$ & $\begin{array}{l}{ }^{*} \mathrm{Ho} \\
\mathrm{CL}\end{array}$ & $\begin{array}{l}\text { va rebre } \\
\text { go.3S. receive }\end{array}$ \\
\hline
\end{tabular}

'Who received the present? Joan received it.'

All these Catalan examples (6)-(9) are subsumed by the clitic lo in Spanish:

10. ¿ $\quad$ a. $\quad$ Has visto a Marc? No, no lo he visto.

b. ¿Comprarás el libro? Sí, lo compraré cuando tenga dinero.

c. ¡Compra el libro! ¡Cómpralo!

d. ¿Compraste el libro? Sí, lo compré ayer.

e. Joan dijo que vendría. Juan lo dijo.

f. No digas eso. No lo digas.

g. $\quad$ Pere es maestro. Pere lo es.

h. Pere es el maestro de Espot. Pere lo es.

i. ¿Quién recibió el regalo? Lo recibió Juan.

(III) The partitive en is used in Catalan for bare NPs (11a), and quantified direct objects (11b); this pronoun does not exist in Spanish.

11
a.
Deixa'm diners.
No
en
tinc
Let me money.
Not
CL
have.1S.
'Let me some money. I don't have any'.
b. No tens
quatre cases, *(en)
tens tres
Not have. 2
four houses, CL
have. $2 \mathrm{~S}$ three

'You don't have four houses, you have three.'

Nonetheless, the feature [ \pm definite] is also present in Standard Spanish ${ }^{2}$ clitics but is only relevant in certain constructions such as topicalizations, in which reduplication with a clitic is obligatory. Thus, a dislocated definite object reduplicates with the clitic $l$ (12a). According to Roca (1992), dislocation of an indefinite direct object yields an ungrammatical term, so a dislocation such as $(12 b)$ is neither possible in Catalan, nor in Spanish. This is so precisely due to the impossibility of the accusative clitic referring to an indefinite object, and not to the fact that indefinites cannot be dislocated (see Roca 1992 for independent evidence). In addition, Arregi (2003) observed that unrestricted scope indefinites can

2 Although related, we will not discuss DO clitic doubling constructions in Porteño Spanish, in which direct object doubling is possible as long as the NP is definite or specific (Jaeggli 1982, 1986; Suñer 1988). 
undergo clitic left dislocation (CLLD), as in (12c), whereas indefinites with restricted scope cannot undergo CLLD, as in (12d):

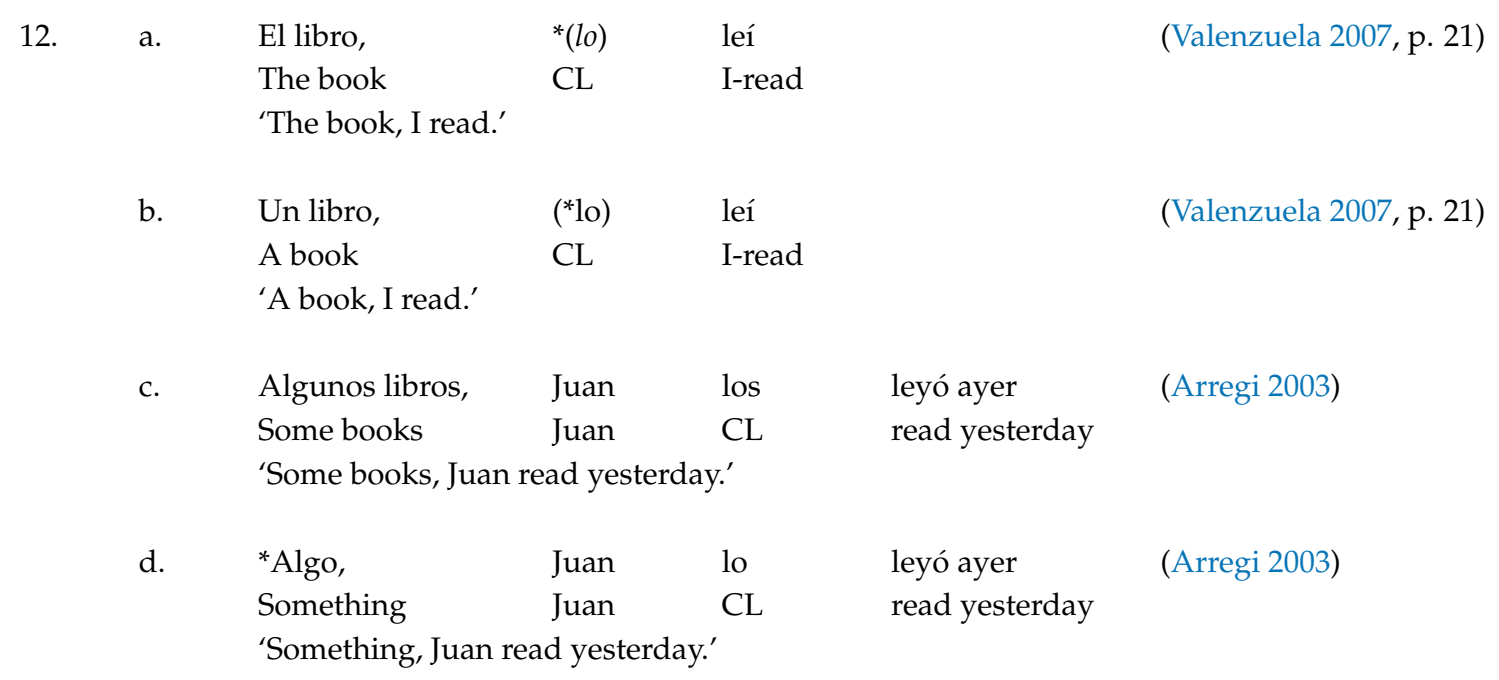

Bare NP objects, on the other hand, can be dislocated, as in (12e), resulting in a null object construction:

$\begin{array}{llll}\text { e. Dinero, no } & \text { tengo } & \text { (Roca 1992, p. 257) } \\ \text { Money, not } & \text { I-have }\end{array}$

Under certain syntactic conditions, Spanish can use a null pro or null variable (Campos 1986):
f. ¿Compraste regalos? Sí, comprée.
(Campos 1986, p.

Notice that Campos (1986) talks in his paper about 'indefinite object drop', but in reality, he only gives examples with bare nouns, not with NPs with the indefinite article because they work somewhat differently. That is, the null pro that Campos (1986) proposes for Spanish seems to work for bare NPs, but not for indefinite NPs; ${ }^{3}$ Campos (1986) clarifies that quantified NPs do not share the same properties. As we saw in (11), Catalan uses the partitive clitic en with quantified direct objects and indefinites with a partitive interpretation.

All these data emphasize the idea that the clitic $l$-and its Spanish equivalents lo/los/la/las—are always marked as [+def], and can only refer to definite NPs in both Spanish and Catalan (Roca 1992). The main difference is that Catalan has more specialized morphosyntactic forms for expressing other semantic features, i.e., the partitive clitic to refer back to quantified or indefinite direct objects with a partitive meaning (Perpiñán 2017), and the unspecified or neuter clitic / $\mathrm{l} /$, different from $l$, which is not marked with the [+def] feature. Catalan and Spanish do not present crosslinguistic differences with respect to the position of the clitic (Uriagereka 1995). For this reason, we believe that the debate between theories of clitic placement is not crucial in this study. Whether the clitic is generated in an argumental position and then raises to a higher functional projection (Kayne 1991), or it is generated in a position outside the verb phrase and associated with the argument through a Spec-Head agreement relationship (Jaeggli 1982, 1986; Sportiche 1996) is unrelated to the bilinguals' task to keep both languages separate, as the same syntactic theoretical assumptions would be adopted for the two languages. The real difficulty, then, resides in the morphophonological expression of the feature [ \pm definite], as Catalan and Spanish have different feature mappings between the forms and the semantic properties.

3 This issue needs further research regarding Spanish theoretical syntax and goes beyond the scope of this paper. 


\section{Previous Studies}

\subsection{The Acquisition of Differential Object Marking}

We know very little about DOM in Catalan and Catalan-Spanish bilingualism since it is not a characteristic feature of Catalan grammar. We know that this is a vulnerable feature in Spanish and other heritage languages which has undergone erosion in animate, specific direct objects and attrition in first generation immigrants in the US (Montrul 2004; Montrul and Bowles 2009; Montrul and Sánchez-Walker 2013; Montrul et al. 2015). Guijarro-Fuentes and Marinis (2009) investigated Spanish DOM in Catalan-dominant bilinguals and English-Spanish bilinguals and found residual optionality in both groups, particularly in the acquisition of interpretable features that relate to the discourse context, such as specificity. Catalan bilinguals produced more errors of commission of the preposition $a$, whereas English-Spanish bilinguals produced more errors of omission of the direct object marker; thus, Catalan speakers overused the personal $a$. Since neither Catalan nor English present DOM in their standard varieties, the authors concluded that the acquisition of interpretable features is not prone to crosslinguistic influence as both L1 groups behaved differently, and that language contact does not influence the path of acquisition for the DOM.

On the other hand, studies on monolingual first language acquisition have shown that DOM in Spanish is fully acquired by the age of three (Rodríguez-Mondoñedo 2008). This author analyzed the data of four Spanish-speaking monolingual children from the CHILDES database (MacWhinney 2000), aged 0;9-3;01 and found that DOM first appears between 1;9 and 2;4 of age, and by age 3, children have $98 \%$ accuracy in DOM during spontaneous production. In a different study, Ticio (2015) investigated seven bilingual children, English-Spanish speakers, aged 1;1-3;6. One of them, Yasmin, from the Llinàs-Grau database is being raised in Barcelona and is exposed to Catalan at daycare. Yasmin only marked one direct object and produced a commission error. According to Ticio, this child left seven accusative objects unmarked, which resulted in ungrammaticalities. One of the examples this author provides as an error is the following: 'Vamos a buscar el pez aqui', ('We are going to look for the fish here', p. 82), produced at 2;5. However, this sentence is perfectly grammatical according to my own intuition. In any case, Ticio (2015) data accuracy rating in DOM usage in these children is around $26 \%$, which is much less compared to the data found for monolingual L1 acquisition. To summarize, all studies on child and adult L2 acquisition, as well as simultaneous and sequential bilingualism have shown significant differences between the acquisition of DOM in a monolingual context compared to its acquisition in an L2 or multi/bilingual context; in a bilingual context, we find protracted development and incomplete acquisition, and we find attrition in L1 migrant generations. All this evidence indicates that DOM is a vulnerable feature in bilingual grammar.

\subsection{The Acquisition of Direct Object Clitics}

The acquisition of clitics in Catalan has been studied almost exclusively for L1 children. Gavarró et al. (2010) and Gavarró et al. (2006) found direct object clitic omission in early child acquisition, with higher omission rates in Catalan than Spanish. Omission has also been attested in Italian (Guasti 1993), French (Jakubowicz et al. 1996, 1997), and in Specific Language Impairment (SLI) for a long period of time (Jakubowicz et al. 1998). The delay and optionality in the appearance of object clitics has been explained as the result of computational complexity since omission or avoidances can alleviate the processing load (Hamann and Belletti 2006), or as the result of other linguistic properties of the language, such as participle agreement (Gavarró Anna et al. 2011); this is the explanation provided by these authors to account for the differences in omission rates between Catalan (a language with participle agreement) and Spanish (no participle agreement). However, Tarrés and Bel (2015), in a study of L2 Catalan children (7-year-olds from Portuguese families in Andorra) found that the use of dative and accusative clitics in L2 Catalan is very similar to that of monolingual Catalan children (around 66\% of correct suppliance, $18 \%$ of omissions), with no errors in gender, number, or position, despite the fact that 
Portuguese has a different position for these clitics. Similar results were found in a follow-up study with more participants, this time also with francophone children (Tarrés and Bel 2017).

In regard to child L2 acquisition, Paradis (2004) investigated object expression in L2 children, aged 7, (L1 English-L2 French) after two years of French schooling in Montreal and found the use of direct object clitics in about $40 \%$ of the possible cases. Omission and clitic position errors are typical in post-puberty L2 Spanish individuals (Duffield et al. 1998; Liceras 1985). This has raised the question of whether the difficulties lie in the acquisition of syntax or in the acquisition of the morphological properties of the clitics; Santoro (2007) found that the morphology of clitics develops later than their syntactic properties. Similarly, Arche and Domínguez (2011), in a study of clitic acquisition of L2 Spanish by English speakers, observed asymmetries between production and comprehension results in an intermediate group, concluding that the appropriate syntactic representation was in place whilst morpho-phonological difficulties remained, supporting the Missing Surface Inflection Hypothesis (Prévost and White 2000). Valenzuela (2007) took into account the semantics of the clitics in an investigation of L2 Spanish CLLD by English-speaking learners, in particular, the specificity of antecedents. She found that while the syntax was acquired properly, the learners overgeneralized the clitic in non-specific contexts, displaying vulnerability at the interpretive level. In another study on the acquisition of Spanish CLLD, Slabakova et al. (2012) proposed an order of acquisition in which narrow syntactic properties are acquired first, followed by syntax-semantics interface properties, and the last properties to be acquired are those of the syntax-discourse interface. Although the present study does not investigate CLLD, these results can serve as an indication of the developmental stages in the acquisition of clitics.

\section{Research Questions}

The linguistic descriptions and comparisons between the two languages clearly show that the Catalan clitic system is morphologically more complex than the Spanish system, with more pairings of semantic properties mapped onto different functional forms. In this study, we focus on the morphological consequences of the semantic feature [ \pm definite] and investigate whether its morphological expression in bilingual Catalan is affected by intense contact with Spanish language. In particular, we question whether Spanish-dominant early bilinguals are able to acquire a new functional category $(/ 1 /$ vs. $/ \mathrm{u} /)$ and its appropriate semantic distribution in Catalan. On the other hand, DOM in Spanish has an intricate semantic system that regulates its appearance; this use of DOM is, prima facie, more complex in Spanish than in Catalan, since, in Standard Catalan, it is mainly regulated by syntax, i.e., it is required in determined syntactic contexts such as topicalizations and with strong pronouns. Thus, Spanish-dominant bilinguals need to reduce their grammatical system and disregard the semantic and pragmatic distribution of DOM. Given these two situations involving the acquisition of one new category - that is, complexifying the grammar vs. the unlearning of one category, simplifying the system-we wonder which process prevails in bilingual grammar, factoring in the role of language dominance.

If simplification always takes place in language contact situations, as McWhorter (2007) and Trudgill (1989) predicted, then we can expect bilingual varieties to have a reduced clitic system with no morphological distinction for definiteness, as well as a grammar system with no DOM specification. If crosslinguitic influence takes place as a consequence of feature activation in bilinguals, then we should find functional interference or functional convergence, as Sánchez (2003) hypothesized. Then, we would expect the activation of functional features in Catalan, triggered by input in Spanish, to result in new configurations of features and feature mappings influenced by Spanish, and finally, we would expect the formation of new structures in Catalan. These new structures may consist of a reassembly of features in semantically or grammatically similar structures, in the form of, for instance, the clitic ho in [+definite] contexts, $l$ in [-definite] contexts, or DOM in non-topicalized contexts. If functional convergence takes place, then we should find a common set of features shared by the bilinguals that are equivalent in the two languages-that is, a fusion of functional features from the two languages 
(Sánchez 2003, 2015). In order to investigate these hypotheses, and given the scarcity of the data on Catalan-Spanish bilingualism, we conducted an exploratory experimental study with data from three different types of bilinguals and two linguistic tasks.

\section{The Study: Methodology}

\subsection{Participants}

Fifty-seven young Catalan-Spanish speakers, most of them with a university degree, between the ages of 20-36 (M (29.1), SD (4.7)) participated in this study. This range of ages was selected so that all participants had been schooled in Catalan, under the Catalan immersion linguistic policy, first established in 1983. The idea of this law is to guarantee that all children know both languages well at the end of the obligatory school system. In order to assess the linguistic profiles of the participants, they completed an exhaustive linguistic background questionnaire (more details below), which classified them into three groups:

Group 1: Catalan-dominant speakers $(n=22)$, who live in the central area of Catalonia (Manresa and surroundings). All these speakers identified themselves as Catalan and not Spanish, and only one of them considered himself to be a balanced bilingual speaker, although the background questionnaire (see below) classified this speaker as Catalan-dominant.

Group 2: Bilingual speakers $(n=15)$, whose L1 is Catalan or who were raised through the one parent/one language strategy and live in the metropolitan area of Barcelona, mostly in Sant Adrià de Besòs and surrounding areas. These are speakers who have been exposed continuously to both languages since birth.

Group 3: Spanish-dominant speakers $(n=20)$, who live in the same neighborhoods in the Metropolitan area of Barcelona that individuals in group 2 do, come from a Spanish family background and use Spanish predominantly.

The goal of this classification was to represent different linguistic populations identified in the last linguistic survey carried out in Catalonia, as explained in the introduction. These three groups represent different points on a bilingual continuum (Perpiñán 2017; Silva-Corvalán 2003), and we believe they can represent different stages in a possible linguistic change.

\subsection{Materials}

\subsubsection{Linguistic Background Questionnaire}

This questionnaire consisted of approximately 50 questions regarding language use, language preference, family origins, amount of exposure to each language, linguistic identification, onset of acquisition of the two languages, and self-evaluation in different linguistic skills in both languages. It was administered on the internet through a survey platform. The data from this task classified the bilingual speakers in the groups described in Section 5.1.

\subsubsection{Acceptability Judgment Task}

The Acceptability Judgment Task (AJT), administered on the same web platform, consisted of a total of 120 pairs of sentences that tested different linguistic constructions. In this study, we analyzed 40 target pairs of sentences, 20 for DOM and 20 for the definite accusative clitic. Participants were instructed to read the pair of sentences and judge the second sentence according to the context introduced by the first one on a 4-point scale: 1 = "sona malament" (sounds bad), 4 = "sona bé" (sounds good). Sentence pairs were counterbalanced for grammaticality; the main independent variables were type of structure, masculine definite clitic and DOM, and each structure had 4 conditions: two grammatical and two ungrammatical. Each structure was analyzed independently. There were 5 tokens per condition and structure ( 2 structures $\times 4$ conditions $\times 5$ tokens $=40$ pairs of sentences). Table 2 presents one example from each category of the DOM structures. 
Table 2. Sample of experimental stimuli in the Acceptability Judgment Task (AJT) for Differential Object Marking (DOM) structures.

\begin{tabular}{ccc}
\hline Personal $a$ & +Definite & - Definite \\
\hline - DOM & $\begin{array}{c}\text { Què fan els pares? } \\
\text { Passegen la seva filla. }\end{array}$ & $\begin{array}{c}\text { Què fan els pacients? } \\
\text { Esperen una infermera. }\end{array}$ \\
\hline $\begin{array}{c}\text { +DOM } \\
\text { (ungrammatical) }\end{array}$ & $\begin{array}{c}\text { Què fan els pares? } \\
\text { *Passegen a la seva filla. }\end{array}$ & $\begin{array}{c}\text { Què fan els pacients? } \\
\text { *Esperen a una infermera. }\end{array}$ \\
\hline English Translation & 'What do the parents do? & 'What do the patients do? \\
& 'They walk her daughter.' & They are waiting for a nurse.' \\
\hline
\end{tabular}

Sentences for the DOM condition manipulated the variable [ \pm definite] and the presence or absence of DOM with transitive verbs. The purpose of these sentences was to empirically assess the acceptability of the DOM in Catalan, in bilingual contexts, in declarative, neutral-context sentences. We only included [+human] objects; all subjects of these sentences were also [+human].

As for the structure masculine clitic, we only included masculine definite antecedents ( 2 animate, 3 inanimate), and manipulated the order of the clitic structures and the presence of the definite clitic $/ l /$, the indefinite one $h o / \mathrm{u} /$ and the ungrammatical null clitic. The combination of variables is exemplified in Table 3.

Table 3. Sample of experimental stimuli in the AJT for masculine clitic structures.

\begin{tabular}{ccc}
\hline Masculine Clitic & Definite Clitic /ll & ${ }^{*}$ Indefinite /u/ or * $\emptyset$ \\
\hline Proclisis & $\begin{array}{c}\text { Qui va rebre el regal? } \\
\text { El va rebre el Joan. }\end{array}$ & $\begin{array}{c}\text { Qui va rebre el regal? } \\
\text { Ho va rebre el Joan. }\end{array}$ \\
\hline Enclisis & $\begin{array}{c}\text { Qui va rebre el regal? } \\
\text { Va rebre'l el Joan. }\end{array}$ & $\begin{array}{c}\text { Qui va rebre el regal? } \\
\text { Va rebre el Joan. }\end{array}$ \\
\hline \multirow{2}{*}{ English Translation } & 'Who received the present? \\
& Joan received it.' \\
\hline
\end{tabular}

\subsubsection{Oral Production Task}

The Oral Production Task (OPT) consisted of a total of 50 scenarios in which a picture was presented, followed by a question about the picture and a guided response that included the transitive verb and the DP to be used. There were 5 contexts with definite human direct objects favouring the presence of DOM according to Spanish grammar (Figure 1), and 5 disfavouring DOM with indefinite human direct objects (Figure 2). The DPs provided in the task, which were the direct object of the transitive verb, always included the definite or indefinite article.
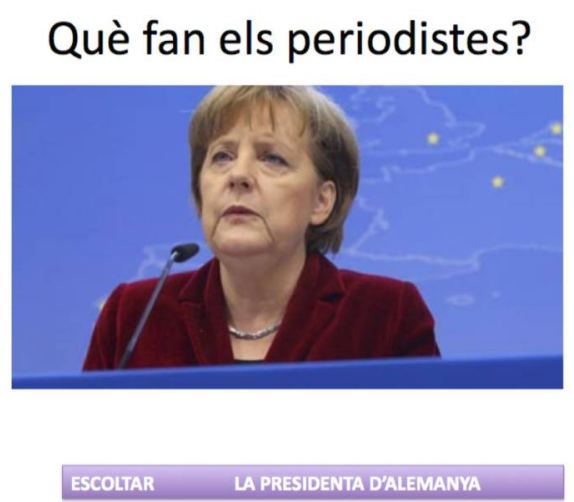

Figure 1. Context eliciting Differential Object Marking (DOM) with a definite direct object. 
13. Figure 1-Translation from Catalan

What do journalists do?

Expected/Possible Response

Escolten la presidenta d'Alemanya

'They listen to the president of Germany.'

\section{Què han fet aquestes dones?}
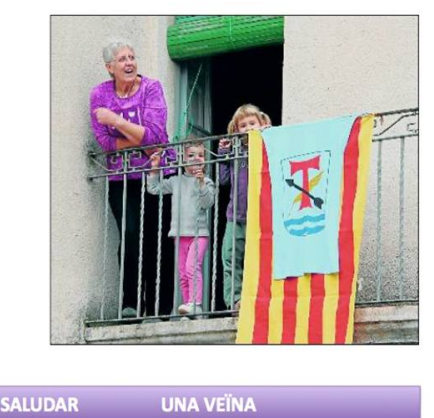

Figure 2. Context eliciting (no) DOM with an indefinite direct object.

14. Figure 2-Translation from Catalan

What have these women done?

Expected/Possible Response

Han saludat una veïna

'They have greeted a neighbour.'

In order to elicit accusative clitics, we included 5 contexts in which a definite masculine singular object was expected to be clitized (Figure 3), and 5 contexts in which a definite feminine singular was expected to be clitized (Figure 4). The tense of these sentences was always in the indefinite preterite, which is an analytical verbal form in Catalan and allows for both enclisis and proclisis.

\section{Qui va guanyar el premi?}

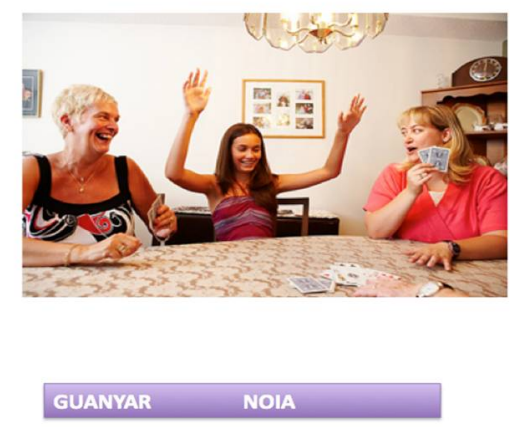

Figure 3. Context eliciting the accusative masculine clitic.

15. Figure 3-Translation from Catalan

Who won the prize?

Expected/Possible Response

El va guanyar la noia/Va guanyar-lo la noia

'The girl won it.'

We also included 5 scenarios in which the accusative clitic elicited was feminine: 


\section{Qui va netejar la flauta?}

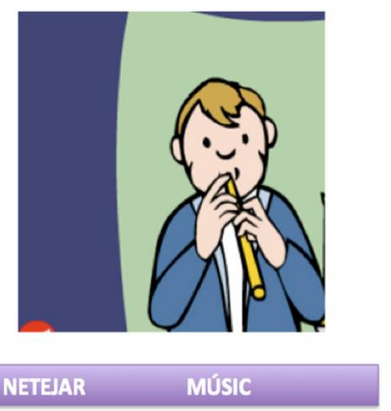

Figure 4. Context eliciting the accusative feminine clitic.

16. Figure 4-Translation from Catalan

Who cleaned the flute?

Expected/Possible Response

La va netejar el músic/Va netejar-la el músic

'The musician cleaned it.'

\section{Results}

\subsection{Linguistic Background Questionnaire}

Responses from the linguistic background questionnaire were transformed into a numerical value-responses that favored Catalan were coded with 1 (for instance, if the family is originally from Catalonia, if they live outside the metropolitan area of Barcelona, if they identified themselves with Catalan, etc.), and responses that favored Spanish were coded as 0; responses that favored both were coded as 0.5 . This calculation served to classify the participants into the abovementioned groups. If the score ranged from 0 to 4.5 , the participant was classified as "Spanish-dominant" $(M=1.75, S D=1.39)$; if the total score ranged from 5 to 9.5, the participants were classified as "Bilingual" $(M=7.93, S D=2.03)$, and if the score ranged from 10 to 13, the participant was classified as "Catalan-dominant" $(M=12.2$, $S D=1.25)$. A one-way ANOVA with the mean scores from the Linguistic Background Questionnaire showed a robust effect of the variable group $(F(2,54)=244.58, p<0.001)$, and the post-hoc test proved that the three groups were statistically different $(p<0.001)$. This is a reliable way of classifying types of bilinguals, similar to the one developed by Birdsong et al. (2012), particularly when proficiency does not necessarily account for degree of bilingualism. Official Catalan proficiency tests, which were deliberately avoided in this study, measure explicit, normative, and standardized knowledge typically taught in the classroom that often differs from street usage.

\subsection{Acceptability Judgment Task}

The participants judged the pairs of sentences on a scale from 1 (sounds bad) to 4 (sound good); the results from each participant were averaged by condition and group and analyzed with a repeated measures ANOVA by linguistic structure.

\subsubsection{Differential Object Marking Results}

In the DOM sentences, we manipulated two variables: the absence/presence of the preposition $a$ and the [ \pm definiteness] of the direct object. The between subjects factor was the bilingual group to which the participant was assigned by means of the linguistic background questionnaire. The average ratings by condition and group are shown in Figure 5. Overall, we can see that all participants largely accepted all sentences, with or without the preposition. 


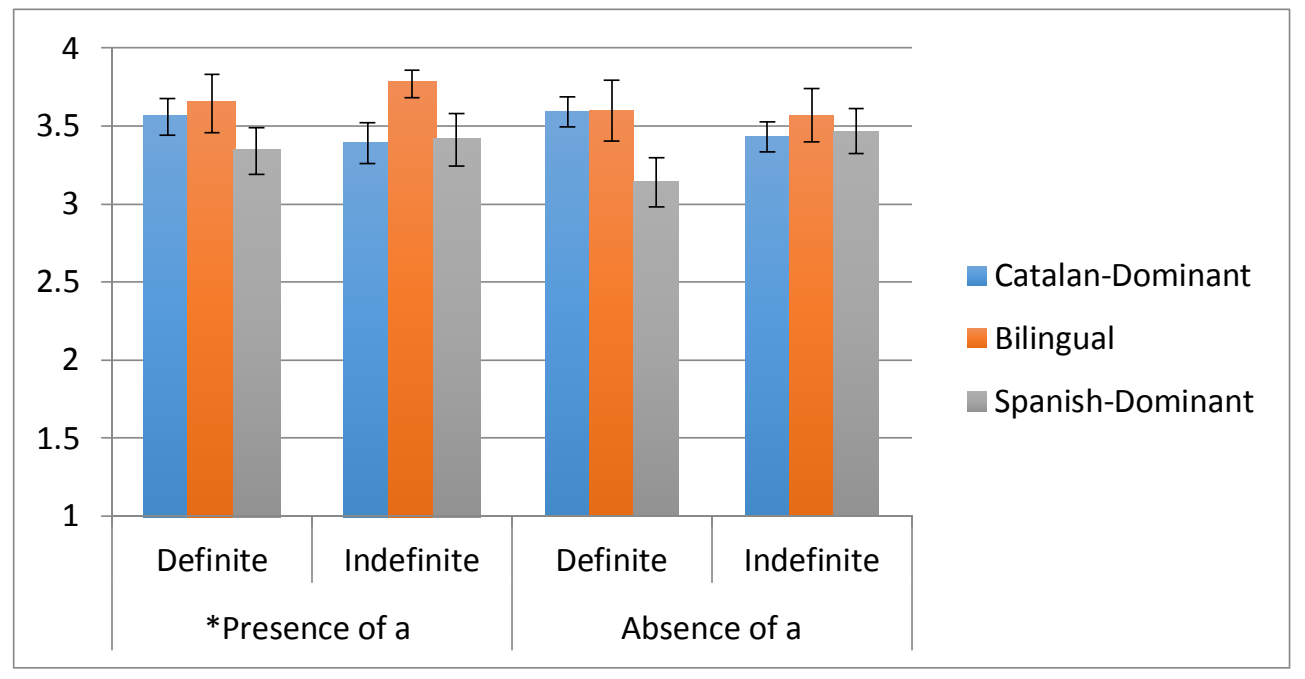

Figure 5. Average ratings for DOM structures, Acceptability Judgment Task (AJT).

The results of the repeated measures ANOVA showed no significant effect of definiteness $(F(1,54)=0.66, p>0.1)$, and no significant effect of the presence/absence of the preposition $a(F(1,54)=0.166, p>0.1)$. There was no interaction between definiteness and preposition $a$ $(F(1,54)=0.037, p>0.1)$, as it would have been expected, pointing towards the idea that our participants, independently of the group they belong to, do not regulate the presence/absence of the DOM according to the definiteness of the direct object. The group factor was also not significant $(F(2,54)=2.31, p>0.1)$. There was only one significant interaction in the results, and that was between definiteness and group $(F(2,54),=6.29, p<0.05)$. This interaction showed that overall, Spanish-dominant bilinguals rated the definite sentences lower, whereas the Catalan-dominant bilinguals rated these sentences significantly higher, independently of the presence/absence of a DOM.

\subsubsection{Accusative Clitics}

As for the accusative clitics, grammatical sentences were submitted to a repeated measures ANOVA, and the results showed that position has a significant effect in the grammatical data $(F(1,54)=8.08, p=0.006)$, as well as the bilingual group $(F(2,54)=3.671, p<0.05)$, and the interaction between position and bilingual group $(F(2,54)=3.306, p<0.05)$. By looking at the descriptive data represented in Figure 6, we can see that proclisis received lower acceptance rates in the non-Catalan-dominant groups; all groups responded similarly in the enclisis syntactic condition. The post-hoc tests with the Bonferroni correction further indicated that the only groups that differed were the Catalan-dominant bilinguals and the Spanish-dominant bilinguals, and only in the proclisis condition $(p=0.012)$; the balanced bilinguals, on the other hand, did not differ from either of the other two groups $(p>0.1)$.

With respect to the ungrammatical sentences, we conducted a multivariate ANOVA, which indicated that, as for the omission of the obligatory clitic, there was a significant difference between groups $(F(2,54)=4.082, p=0.022)$; the Bonferroni correction indicated that the Spanish-dominant bilinguals differed from the Catalan-dominant bilinguals $(p=0.23)$. Finally, with respect to the ungrammatical $h o / \mathrm{u} /$, the results of the ANOVA showed a significant difference between groups $(F(2,54)=23.294, p<0.001)$, and the post-hoc test further showed that the only different group was the Spanish-dominant bilinguals $(p<0.001)$, whereas Catalan-dominant and balanced bilinguals did not differ from each other $(p=1)$. This result is easily observable in Figure 6 , which shows clearly how the Spanish-dominant group accepted the sentences with the clitic ho as grammatical. 


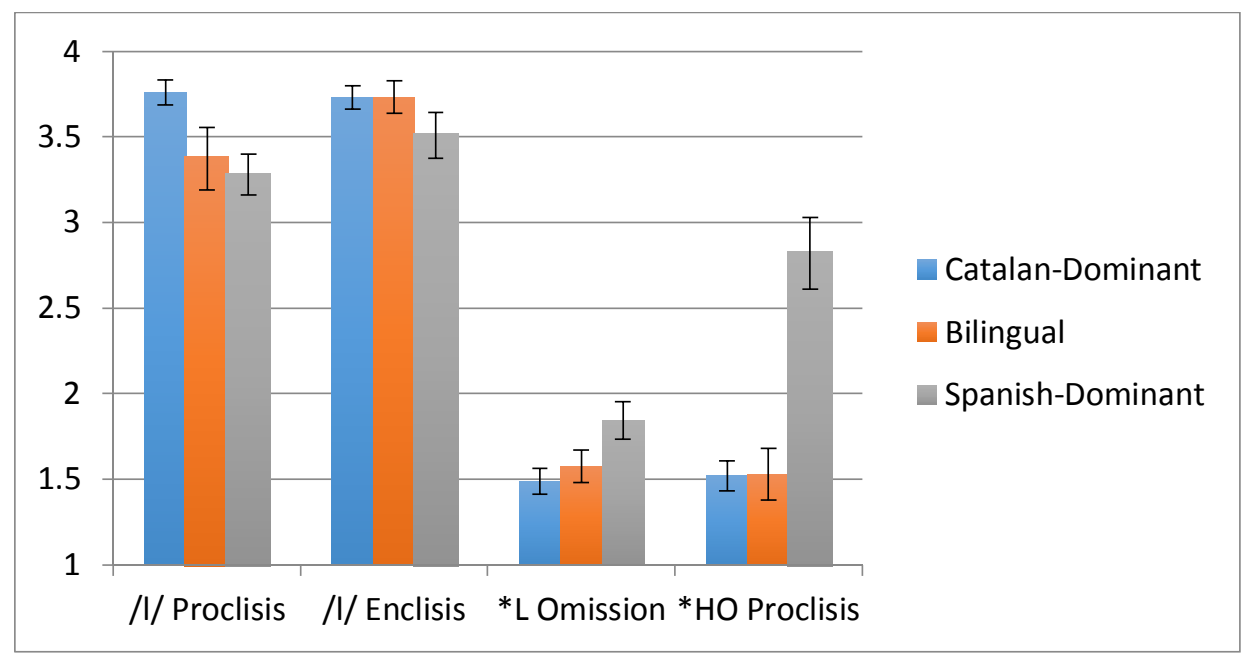

Figure 6. Average ratings for accusative clitic structures, AJT.

\subsection{Production Results}

The sentences elicited in the oral task were coded according to the structure produced, and in the case of the DOM contexts, participants could produce or leave out the preposition $a$; as for the accusative clitics, sentences were coded according to the position of the clitic, whether the clitic was produced or omitted, and by the clitic produced. The percentages of structures produced for each construction were calculated by token and participant and then averaged by condition and group.

\subsubsection{Production of Differential Object Marking}

As described in the methodology section, the production task presented definite and indefinite human direct object contexts, which could elicit the presence/absence of a DOM. Table 4 displays the percentages of production/omission of the preposition according to the semantic features of the DO and the group of bilinguals.

Table 4. Percentages and (counts) of absence/presence of DOM by group and context.

\begin{tabular}{ccc}
\hline & *Presence of DOM & Absence of DOM \\
\hline Definite Direct Object (DO) & & \\
\hline Catalan-Dominant & $22 \%$ & $78 \%$ \\
$n=21$ & $(23)$ & $(82)$ \\
\hline Balanced Bilinguals & $37 \%$ & $60 \%$ \\
$n=15$ & $(28)$ & $(45)$ \\
\hline Spanish-Dominant & $38 \%$ & $55 \%$ \\
$n=19$ & $(36)$ & $(52)$ \\
\hline Indefinite DO & & $71 \%$ \\
\hline Catalan-Dominant & $13 \%$ & $(75)$ \\
\hline Balanced Bilinguals & $(14)$ & $63 \%$ \\
& $25 \%$ & $(47)$ \\
\hline Spanish-Dominant & $(19)$ & $50 \%$ \\
& $41 \%$ & $(47)$ \\
\hline
\end{tabular}

Raw data were submitted to a Chi-square test of independence to examine the relationship between definiteness and the presence/absence of DOM. The results were not significant $(p<0.1)$; for this reason, 
we decided to collapse the data and remove the consideration of whether the context was definite or indefinite. We resubmitted the collapsed data to another Chi-square test to evaluate the relationship between the presence/absence of DOM and the group. This resulted in a significant difference $\left(\chi^{2}(2,507)=25.144, p<0.001\right)$, confirming that, overall, Spanish-dominant bilinguals produced more DOMs and omitted less prepositions across contexts than the Catalan-dominant bilinguals.

\subsubsection{Production of Clitics}

Generally speaking, all participants produced the target construction most of the time, and all groups overwhelmingly preferred proclisis over enclisis. Spanish-dominant speakers seemed to use less proclisis than the other two groups, but this difference did not reach statistical significance. In contrast to what we observed in the AJT, there was very little production of the clitic ho $/ \mathrm{u}$ / in a definite context; interestingly enough, this ungrammatical and very scarce appearance of $/ \mathrm{u}$ / was produced by Spanish-dominant bilinguals not only in masculine, but also in feminine contexts. The frequency of clitic production by each type of bilingual is displayed in Table 5 .

Table 5. Percentages of type of clitic produced.

\begin{tabular}{ccccc}
\hline & Proclisis & Enclisis & ${ }^{*}$ ho & Omission \\
\hline Feminine DO & & & & \\
Catalan-Dominant & $92.4 \%$ & $6.7 \%$ & $0 \%$ & $0.9 \%$ \\
Balanced Bilinguals & $93.3 \%$ & $6.7 \%$ & $0 \%$ & $0 \%$ \\
Spanish-Dominant & $78.9 \%$ & $8.4 \%$ & $5.3 \%$ & $2.1 \%$ \\
\hline Masculine DO & & & & \\
Catalan-Dominant & $90 \%$ & $5.7 \%$ & $0.9 \%$ & $1.9 \%$ \\
Balanced Bilinguals & $90.7 \%$ & $2.7 \%$ & $0 \%$ & $0 \%$ \\
Spanish-Dominant & $77.9 \%$ & $2.1 \%$ & $3.2 \%$ & $5.3 \%$ \\
\hline
\end{tabular}

A multivariate ANOVA indicated no statistical significant differences between groups for any of the conditions/structures investigated; all contrasts and post-hoc correlations for between subjects tests had significance levels of $p>0.5$.

\section{Discussion}

The first interesting pattern that we observed in the results is the asymmetry between acceptability and production data, whereby acceptability data are significantly more distant from the standard grammar than the production data, with higher rates of acceptance of innovative variants and more optionality than in production data. I interpret this not as a task or methodological effect, per se, as an anonymous reviewer suggests, but as a result of the type of knowledge that participants engage with when responding to each task. Indeed, these results are expected, as comprehension occurs before production, and hence, new varieties need to be first understood and accepted in order for the speaker to produce them. It could be the case that these non-standard forms with $/ \mathrm{u} /$ in definite contexts, for instance, are only heard by the Spanish-dominant bilinguals, and hence, accepted, but not produced, by them. One can hypothesize that adult second language learners, with whom the Spanish-dominant bilinguals are in constant contact, produce these non-standard forms, and then, Spanish-dominant bilinguals incorporate them into their receptive knowledge of the language but not into their productive system.

With respect to DOM, all participants overwhelmingly accepted all sentences, with or without $\mathrm{DOM}$, in definite and indefinite contexts. That is, there is a generalized variability with respect to Catalan DOM, which results in [+human] direct objects optionally appearing with or without the preposition $a$, in all groups of bilinguals. This is a very interesting outcome that suggests functional convergence in the grammar of all types of bilinguals-the three groups presented similar results, accepting the ungrammatical presence of DOM at the same time that they accepted the absence of DOM 
in their Catalan grammar, a result that cannot be accounted for by simply assuming crosslinguistic interference from Spanish. Recall that the absence of the preposition $a$ in definite direct objects is completely unacceptable in Spanish, and variable in indefinite contexts. This indicates that the bilinguals' intuitions regarding Catalan are different from both Standard Catalan and Standard Spanish-bilinguals accept a new distinctive variety that shares features from both Catalan and Spanish, but that also differs from both. This is precisely the definition of functional convergence according to Sánchez $(2003,2015)$ : a fusion of functional features from the two languages that creates a new bilingual variety. In this case, the DOM in the bilingual grammar presents pure optionality in [+human, \pm definite] direct objects. We can only speculate whether this optionality is emerging in the Catalan-dominant bilinguals, as in the grammar of L1 attriters, and residual in the grammar of the Spanish-dominant bilinguals, as in near-native adult L2 learners (Sorace 2005). It remains for future research whether the Spanish grammar of these bilinguals (Spanish spoken in Catalonia, or the bilingual Spanish) also present optionality in DOM use. If this were the case, then we would have a clear case of convergence of both languages, where bilinguals, instead of keeping the two grammars separate in their minds, have fused them, merging the restrictions and idiosyncrasies both languages. This alleviates the cognitive load required to maintain and suppress each language individually. In that sense, linguistic convergence is promoted through processing economy considerations (Muysken 2000). The frequent activation of both languages favors the combination of rules, that is, functional convergence (Sánchez 2003), in this case resulting in optionality. If the input these bilinguals receive in both languages also presents instability and variation in DOM, then this further reinforces the optionality. Moreover, the necessity of DOM in certain syntactic contexts in Standard Catalan (with dislocations, with strong pronouns, etc.) also reinforces the presence of this preposition in the grammar.

The findings from the production data with respect to DOM are somewhat different from those from the AJT given that the Catalan-dominant group omitted the preposition significantly more often in definite and indefinite contexts compared to the Spanish-dominant group, at the same time that the Spanish-dominant group produced DOM significantly more frequently. These results are more conservative than those of the AJT in the sense that they conform more closely to the grammar of Standard Catalan on one side, and the grammar of Spanish on the other, indicating some degree of transfer from Spanish into Catalan in the production of Spanish-dominant bilingualism. Taken together, the DOM results lead us to conclude that the definiteness/specificity feature is not relevant in the distribution of DOM in Catalan, not even for Spanish-dominant bilinguals. This lack of a definiteness effect is expected in Catalan as DOM in Standard Catalan is regulated by syntactic restrictions and not semantic ones. This finding would not be expected in a language with heavy crosslinguistic influence from Spanish. Thus, this variety with optional DOM is by no means simply the result of feature transfer from Spanish, the dominant language, but rather, the outcome of an internal evolution together with external factors.

To sum up, in regard to DOM in Catalan, the results in the AJT are far from being categorical and display ample optionality in all types of bilinguals, with no clear preference or rejection for sentences with (ungrammatical) or without (grammatical) DOMs. In fact, all sentences were accepted as equally grammatical—-those with the preposition and those without it—independently from the semantic context in which the preposition appears/is omitted. All types of bilinguals accept DOM as part of their Catalan variety, or at least clearly accept it as 'sounds good'. The presence of DOM does not result in any type of ungrammaticality in the Catalan competence of these speakers, at least not in [+human] contexts. These results go even further than Hualde's claim which proposed that spoken Catalan is a DOM language in human contexts, since our participants also accepted DOM in written Catalan. It is evident that the grammar of Catalan has evolved to the point of optionally accepting DOM in all human direct object contexts, at the same time that the etymological option in which DOM is absent is simultaneously retained-a mixture of both grammars coexist in the bilingual mind as they are reinforced by input from both languages, to the point of fusing their characteristics. 
It remains for further research whether we would find the same results in [-human] and [-animate] contexts. At the same time that Catalan seems to be a DOM language with human direct objects, it is equally plausible without the preposition in the same contexts. This variability cannot be accounted for only by crosslinguistic influence or functional interference from Spanish, as Spanish grammar would reject these ungrammatical DOM sentences. Guijarro-Fuentes and Marinis (2009) reached similar conclusions with Spanish data from Catalan-dominant bilinguals, as they overused the preposition $a$ in inappropriate contexts, a fact that could not be explained by crosslinguistic influence. These authors further concluded that language contact does not influence the path of acquisition for DOM, a statement with which we do not completely agree. Whereas it is true that crosslinguistic influence from Spanish cannot be the only explanation of the present Catalan grammar of bilinguals, we would like to point out that language contact outcomes do not need to have a unique directionality, that is, influence from the majority language to the minority language. It can be the case, as we have found here, that bilinguals find creative solutions to cope with the pressure of keeping two languages in continuous activation. The combination of constraints from the two languages can be one of those solutions. Our bilingual speakers have created a new variety in which Catalan DOM is optional in definite and indefinite contexts. It seems that both solutions, the Catalan option without DOM and the Spanish option with DOM, are similarly available and coexist in the bilingual mind and the bilingual community. It remains for further research to investigate whether the Spanish spoken in Catalonia also presents signs of optionality with respect to DOM use and only then can we conclude that signs of convergence appear in both languages in contact.

Thus, the coexistence of these two languages, that is, the language contact, have afforded this optionality in Catalan and hence, the new bilingual variety. This is in accordance with Silva-Coravalán's claim regarding language change in language contact situations-we believe that bilingualism favours the creation of new contact varieties, and thus, promotes or accelerates language change. Recall that the presence of DOM was already attested for in Medieval Catalan and probably also in Vulgar Latin, so external forces (the presence of Spanish) are basically accelerating an already ongoing internal process. This change does not incorporate foreign elements into the grammar but expands the contexts in which the vernacular DOM can appear. Although we do not yet know the exact new distribution of DOM in bilingual Catalan, we do not believe this is necessarily a matter of language simplification; in contrast, if anything, it would be a case of language complexification as it is adding/expanding a new morphological marker. Still, until this phenomenon is investigated in other semantic, pragmatic, and syntactic contexts, we can only speculate about this issue.

With respect to the definite accusative clitics, the AJT and the production data showed that the Spanish-dominant speakers do not exactly accept/produce proclisis at the same rates as the Catalan-dominant speakers, an issue that we will not address in depth here and remains for further research; on the other hand, Spanish-dominant bilinguals also accepted ungrammatical omissions of clitics more frequently than Catalan-dominant speakers. However, these differences did not reach statistical significance. These two features have also been found in data from adult L2 learners (Duffield et al. 1998; Duffield et al. 2002; Duffield and White 1999; Liceras 1985), in which the L2 learners had difficulties with clitic climbing and omitted obligatory clitics. Differences aside, it is interesting that we found similar results in the Catalan of Spanish-dominant bilinguals, whose first language shares linguistic features with Catalan (clitic climbing and obligatory definite clitics). Thus, although not reaching statistical significance, we see a pattern here represented by a bilingualism outcome: even when the two languages at play behave similarly, the non-dominant language can present typical characteristics of developmental grammar.

As for the indefinite clitic ho in ungrammatical contexts, we found large differences in acceptance rates in the AJT in the grammar of Spanish-dominant bilinguals compared to the other two groups. For these speakers, ho is a seemingly plausible substitute of the clitic /1/ in definite contexts, thus, the semantic distinction of this clitic [+definite] is not correctly mapped with the appropriate functional category and its morphological spell out. Conversely, the production of ho in inappropriate contexts 
is very scarce, showing again that the general intuition of bilinguals is more accommodating to innovative varieties; however, their production is more unadventurous and abides more closely by the rules of the standard grammar. Interestingly enough, the sparse ungrammatical production of $h o$ appears in masculine and feminine contexts, indicating that Spanish-dominant speakers may consider the clitic ho a gender-neutral pronoun that is also available for definite contexts. We believe that the acceptance of $h o$ by the Spanish-dominant speakers is not an internal evolution of the Catalan language or a combination of constraints but is due to crosslinguistic influence from Spanish. Indeed, Catalan-dominant speakers as well as balanced bilinguals do not accept this option in their native Catalan grammar, as the use of ho in definite environments is an external influence from Spanish that has not been incorporated, at least not yet, into the bilingual system. We believe that the fact that Spanish does not distinguish between definite and indefinite direct object clitics and that the Spanish archimorpheme lo subsumes all the uses, increasing the frequency of this clitic in the input favors the activation of an underspecified clitic $l o$ in the Catalan grammar of Spanish-dominant bilinguals that morphologically maps onto $h o / \mathrm{u} /$ in Catalan.

Thus, these two structures (DOM and $/ \mathrm{l} / \mathrm{vs}$. / u/) have different natures in terms of language contact phenomena and are at different stages on a potential language change path. Both, nonetheless, are somewhat affected by the intense contact with Spanish. Catalan DOM is clearly undergoing language change through language convergence, whereas the status of ho is that of circumstantial influence from Spanish to Catalan. Both phenomena start at the level of comprehension/acceptance, and later may expand to the production system and be incorporated into bilingual grammar. Both innovative phenomena are first found, or found with a higher frequency, in the Catalan grammar of Spanish-dominant bilinguals, and are later adopted by the balanced bilinguals. As mentioned before, it could be the case that these innovative forms start out in the grammar of child L2 learners who remain dominant in their first language, or even in the grammar of adult L2 learners, not depicted here. In any case, we believe that Spanish-dominant bilinguals are the agents of linguistic change.

The final logical question is why some features permeate and change in a bilingual context while others do not seem to do so easily, even when they share the same semantic distinctions. This intralinguistic question would vary from language to language, but we believe that vulnerable or difficult elements for L2 learners would also be difficult and susceptible to change in language contact situations. Many studies have demonstrated that Spanish DOM is a vulnerable feature in L2, heritage languages and has been subject to attrition in immigrant communities (Montrul and Sánchez-Walker 2013; Montrul et al. 2015). If DOM has been reported to be vulnerable in other asymmetrical bilingualism situations, we can only presume that it will also be difficult in the bilingual context at hand. Furthermore, its distribution in Catalan language has been expanding in certain contexts along the history of Catalan language as an internal phenomenon, and more variability in the input is already apparent. This (re)distribution of DOM in Catalan has been accelerated by contact with Spanish. On the other hand, the distribution of /u/vs. / / has not presented variability in the Catalan language and remains stable in the grammar of Catalan-dominant and balanced bilinguals, in the sense that they do not accept its appearance in inappropriate contexts. We can only imagine that this external feature will not permeate into bilingual Catalan grammar, as its inclusion is not favored by the internal evolution of the language. With respect to the final research question regarding the directionality of language change, we can now conclude that the attested optionality does not necessarily imply simplification or erosion. Catalan has expanded its use of DOM and has created a new redistribution of feature-form mappings. These mappings may remain indeterminate for some time, but in any case, we do not believe this constitutes an instance of language simplification.

\section{Conclusions}

This study investigated the expression of direct objects in the Catalan grammar of three different types of Catalan-Spanish bilinguals: Catalan-dominant, balanced, and Spanish-dominant bilinguals. It focused on the expression of DOM on one hand, and the distribution of /1/ vs. / $\mathrm{u} /$ clitics, on the 
other. Both linguistic phenomena are regulated by semantic distinctions in terms of definiteness and/or specificity. This study concluded that the acquisition of definiteness and/or specificity do not present major problems for non-native speakers, as all speakers had a good understanding of the intricacies of the structures. We observed that DOM has been expanded to further syntactic structures in the grammar of all of the groups of bilinguals that we investigated, and that $/ \mathrm{u} /$ is anecdotally used in definite contexts by Spanish-dominant bilinguals. Following Sánchez $(2003,2015)$ terminology, we analyzed these findings as examples of functional convergence in the case of DOM, and as functional interference in the case of $/ \mathrm{u} /$. The combination of constraints from Catalan and Spanish, that is, functional convergence, has created a new language variety, the bilingual variety. As opposed to Trudgill (1989) and McWhorter (2007), we do not believe this is a case of language simplification, since Catalan is expanding its use of DOM and in a way, complexifying its grammar and the (re)distribution of DOM. This is, though, a case of ample optionality and indeterminacy, which is now a native feature of bilingual grammar. We consider this to be an example of diachronic change accelerated by the intense contact with Spanish, as hypothesized by Silva-Corvalán (1994). We further hypothesize that the agents of this language change are the less dominant bilinguals in Catalan, that is, the child L2 learners of Catalan who remain Spanish-dominant speakers, or even more likely, the adult L2 learners of Catalan who were not depicted in this study.

Acknowledgments: This research was supported by the Social Sciences and Humanities Research Council of Canada. I would like to thank also Mònica Tarrés and Adriana Soto-Corominas for their help in the data collection and transcription. Finally, I would like to express my gratitude to the council of Sant Adrià del Besòs for allowing me to use their facilities to collect data.

Conflicts of Interest: The author declares no conflict of interest.

\section{References}

Aissen, Judith. 2003. Differential Object Marking: Iconicity vs. Economy. Natural Language \& Linguistic Theory 21: 435-83.

Arche, María J., and Laura Domínguez. 2011. Morphology and syntax dissociation in SLA: A study on clitic acquisition in Spanish. In Linguistik Aktuell/Linguistics Today. Edited by Alexandra Galani, Glyn Hicks and George Tsoulas. Amsterdam: John Benjamins Publishing Company, vol. 178, pp. 291-320.

Arregi, Karlos. 2003. Clitic Left Dislocation Is Contrastive Topicalization. University of Pennsylvania Working Papers in Linguistics 9: 31-44.

Bel, Aurora. 2002. Les funcions sintàctiques. In Gramàtica del Català Contemporani I, II i III. Edited by Joan Solà, M. Rosa Lloret, Mascaró Joan and Manuel Pérez Saldanya. Barcelona: Editorial Empúries, pp. 1075-147.

Birdsong, David, Libby M. Gertken, and Mark Amengual. 2012. Bilingual Language Profile|An Easy-to-Use Instrument to Assess Bilingualism. Austin: COERLL, University of Texas at Austin.

Campos, Héctor. 1986. Indefinite Object Drop. Linguistic Inquiry 17: 354-59.

De Borja Moll, Francesc. 1968. Gramàtica Catalana: Referida Especialment a Les Illes Balears. Palma de Mallorca: Moll.

Duffield, Nigel, Silvina Montrul, Joyce Bruhn de Garavito, and Lydia White. 1998. Determining L2 Knowledge of Spanish Clitics On-Line and Off-Line. Paper presented at Annual Boston University Conference on Language Development, Boston, MA, USA, November 2-4; vol. 22, pp. 177-88.

Duffield, Nigel, and Lydia White. 1999. Assessing L2 Knowledge of Spanish Clitic Placement: Converging Methodologies. Second Language Research 15: 133-60. [CrossRef]

Duffield, Nigel, Lydia White, Joyce Bruhn De Garavito, Silvina Montrul, and Philippe Prévost. 2002. Clitic Placement in L2 French: Evidence from Sentence Matching. Journal of Linguistics 38: 487-525. [CrossRef]

Escandell-Vidal, M. Victoria. 2009. Differential object marking and topicality: The case of Balearic Catalan. Studies in Language 33: 832-85. [CrossRef]

Fabra, P. 1918. Gramàtica Catalana. Barcelona: Institut d'Estudis Catalans.

Fabra, P. 1956. Gramàtica Catalana. Barcelona: Teide. 
Gavarró, Anna, Meritxell Mata, and Eulàlia Ribera. 2006. L'omissió dels clítics d'objecte i partitius en el català infantil: dades espontànies. In La Gramàtica Pronominal del Català: Variació, Evolució, Funció = The Grammar of Catalan Pronouns: Variation, Evolution, Function. Edited by Claus D. Pusch and Susann Fischer. Aachen: Shaker, pp. 27-46.

Gavarró, Anna, Vicenç Torrens, and Ken Wexler. 2010. Object Clitic Omission: Two Language Types. Language Acquisition 17: 192-219. [CrossRef]

Gavarró Anna, Maria Teresa Guasti, Laurice Tuller, Philippe Prévost, Adriana Belletti, Luca Cilibrasi, Hélène Delage, and Mirta Vernice. 2011. The acquisition of partitive clitics in Romance five-years-olds. Iberia 3: 1-19.

Guasti, Maria Teresa. 1993. Verb Syntax in Italian Child Grammar: Finite and Nonfinite Verbs. Language Acquisition 3: 1-40. [CrossRef]

Guijarro-Fuentes, Pedro, and Theodoros Marinis. 2009. The Acquisition of the Personal Preposition a by Catalan-Spanish and English-Spanish Bilinguals. In Selected Proceedings of the 11th Hispanic Linguistics Symposium. Edited by Joseph Collentine, Maryellen García, Barbara Lafford and Francisco Marcos Marín. Somerville: Cascadilla Proceedings Project, pp. 81-92.

Hamann, Cornelia, and Adriana Belletti. 2006. Developmental patterns in the acquisition of the complement clitic pronouns. Rivista di Grammatica Generativa 31: 39-78.

Hawkins, Roger, and Cecilia Yuet-hung Chan. 1997. The Partial Availability of Universal Grammar in Second Language Acquisition: The "Failed Functional Features Hypothesis". Second Language Research 13: 187-226. [CrossRef]

Hualde, Jose Ignacio. 1992. Catalan. London: Routledge.

Idescat. 2013. Generalitat de Catalunya. Idescat (Institut d'Estadística de Catalunya). Available online: https: / / www.idescat.cat/ (accessed on 14 December 2017).

Jaeggli, Osvaldo. 1982. Topics in Romance Syntax. Dordrecht: Foris Publications.

Jaeggli, Osvaldo. 1986. Three issues in the Teory of Clitics: Case, Doubled NPs and Extraction. In Syntax and Semantics: The Syntax of Pronominal Clitics. Edited by Hagit Borer. Orlando: Academic Press, vol. 19, pp. 15-42.

Jakubowicz, Celia, Natascha Müller, Ok-Kyung Kang, Beate Riemer, and Catherine Rigaut. 1996. On the Acquisition of the Pronominal System in French and German. Proceedings of the Annual Boston University Conference on Language Development 20: 374-85.

Jakubowicz, Celia, Natascha Müller, Beate Riemer, and Catherine Rigaut. 1997. The Case of Subject and Object Omissions in French and German. In Proceedings of the Annual Boston University Conference on Language Development. Somerville: Cascadilla Press, vol. 21, pp. 331-42.

Jakubowicz, Celia, Lea Nash, Catherine Rigaut, and Christophe-Loic Gerard. 1998. Determiners and Clitic Pronouns in French-Speaking Children with SLI. Language Acquisition 7: 113-60. [CrossRef]

Kayne, Richard S. 1991. Romance Clitics, Verb Movement, and PRO. Linguistic Inquiry 22: 647-86.

Lardiere, Donna. 2008. Feature assembly in second language acquisition. In The Role of Formal Features in Second Language Acquisition. Edited by Juana Liceras, Helen Goodluck and Helmut Zobl. Mahawah: Lawrence Erlbaum, pp. 106-40.

Leonetti, Manuel. 2004. Specificity and Differential Object Marking in Spanish. Catalan Journal of Linguistics 3: 75-114. [CrossRef]

Liceras, Juana M. 1985. The Value of Clitics in Non-Native Spanish. Second Language Research 1: 151-68. [CrossRef] López, Luis. 2012. Indefinite Objects Scrambling, Choice Functions, and Differential Marking. Cambridge: The MIT Press.

MacWhinney, Brian. 2000. The CHILDES Project: Tools for Analyzing Talk, 3rd ed. Mahwah: Lawrence Erlbaum Associates.

McWhorter, John. 2007. Language Interrupted: Signs of Non-Native Acquisition in Standard Language Grammars. Oxford: Oxford University Press US.

Meier, Harri. 1947. O problema do acusativo preposicional no catalão. Boletim de Filologia 8: 237-60.

Montrul, Silvina. 2004. Subject and Object Expression in Spanish Heritage Speakers: A Case of Morphosyntactic Convergence. Bilingualism: Language and Cognition 7: 125-42. [CrossRef]

Montrul, Silvina, and Melissa Bowles. 2009. Back to basics: Incomplete knowledge of Differential Object Marking in Spanish heritage speakers. Bilingualism: Language and Cognition 12: 363-83. [CrossRef]

Montrul, Silvina, Rakesh Bhatt, and Roxana Girju. 2015. Differential object marking in Spanish, Hindi, and Romanian as heritage languages. Language 91: 564-610. [CrossRef] 
Montrul, Silvina, and Noelia Sánchez-Walker. 2013. Differential Object Marking in Child and Adult Spanish Heritage Speakers. Language Acquisition 20: 109-32. [CrossRef]

Gathercole, Virginia C. Mueller, and Enlli Môn Thomas. 2009. Bilingual first-language development: Dominant language takeover, threatened minority language take-up. Bilingualism: Language and Cognition 12: 213-37. [CrossRef]

Muysken, Pieter. 2000. Bilingual Speech. Cambridge: Cambridge University Press.

Paradis, Johanne. 2004. The Relevance of Specific Language Impairment in Understanding the Role of Transfer in Second Language Acquisition. Applied Psycholinguistics 25: 67-82. [CrossRef]

Pereda i Parramon, Joan. 1986. Contribució a l'estudi de les preposicions en el Tirant lo Blanch (Primera part). Llengua E Literatura 1: 51-109.

Pereda i Parramon, Joan. 1987. Contribució a l'estudi de les preposicions en el Tirant lo Blanch (Segona part). Llengua E Literatura 2: 19-66.

Perpiñán, Silvia. 2017. Catalan-Spanish bilingualism continuum: The expression of non-personal Catalan clitics in the adult grammar of early bilinguals. Linguistic Approaches to Bilingualism 7: 477-513. [CrossRef]

Prévost, Philippe, and Lydia White. 2000. Missing Surface Inflection or Impairment in Second Language Acquisition? Evidence from Tense and Agreement. Second Language Research 16: 103-33. [CrossRef]

Roca, Francesc. 1992. Object Clitics in Spanish and Catalan. In Catalan Working Papers in Linguistics. Girona: Universitat de Girona, pp. 245-80.

Rodríguez-Mondoñedo, Miguel. 2008. The acquisition of Differential Object Marking in Spanish. Probus 20: 111-45. [CrossRef]

Rohlfs, Gerhard. 1971. Autour de l'accusatif prépositionnel dans les langues romanes. Revue de Linguistique Romane 35: 312-34.

Ruaix i Vinyet, Josep. 1994. Observacions Crítiques i Pràctiques Sobre el Català D'avui, 1st ed. Moià: Ruaix, vol. 1.

Salvador, Vicent, and Manuel Pérez Saldanya. 1993. Transitivité et interférence linguistique: La construction a + complément d'objet direct en espagnol et en catalan. In Contrastes. Monogàfic sobre estudis hispànics. Barcelona: Universitat de Barcelona, pp. 39-67.

Sánchez, Liliana. 2003. Quechua-Spanish Bilingualism: Interference and Convergence in Functional Categories. Amsterdam: John Benjamins.

Sánchez, Liliana. 2015. Crosslinguistic influences in the mapping of functional features in Quechua-Spanish Bilingualism. In The Acquisition of Spanish in Understudied Language Pairings. Edited by Tiffany Judy and Silvia Perpiñán. Amsterdam: John Benjamins, pp. 19-48.

Sancho Cremades, Pelegrí. 2002. La preposició i el sintagma preposicional. In Gramàtica del Català Contemporani I, II i III. Edited by Joan Solà, M. Rosa Lloret, Mascaró Joan and Manuel Pérez Saldanya. Barcelona: Editorial Empúries, pp. 1689-796.

Santoro, Maurizio. 2007. Second Language Acquisition of Italian Accusative and Dative Clitics. Second Language Research 23: 37-50. [CrossRef]

Segarra, Mila. 1987. Història de la Normativa Catalana, 2nd ed. Barcelona: Enciclopèdia Catalana.

Silva-Corvalán, Carmen. 1986. Bilingualism and Language Change: The Extension of estar in Los Angeles Spanish. Language 62: 587-608. [CrossRef]

Silva-Corvalán, Carmen. 1994. The Gradual Loss of Mood Distinctions in Los Angeles Spanish. Language Variation and Change 6: 255-72. [CrossRef]

Silva-Corvalán, Carmen. 2003. Linguistic consequences of reduced input in bilingual first language acquisition. In Linguistic Theory and Language Development in Hispanic Languages. Edited by Silvina Montrul and Francisco Ordóñez. Somerville: Cascadilla Press, pp. 375-97.

Silva-Corvalán, Carmen. 2008. The Limits of Convergence in Language Contact. Journal of Language Contact 2: 213-24. [CrossRef]

Slabakova, Roumyana. 2009. Features or parameters: Which one makes second language acquisition easier, and more interesting to study? Second Language Research 25: 313-24. [CrossRef]

Slabakova, Roumyana, Paula Kempchinsky, and Jason Rothman. 2012. Clitic-doubled left dislocation and focus fronting in L2 Spanish: A case of successful acquisition at the syntax-discourse interface. Second Language Research 28: 319-43. [CrossRef]

Solà, Joan. 1994. Sintaxi Normativa: Estat de la Qüestió. Barcelona: Empúries. 
Sorace, Antonella. 2005. Selective optionality in language development. In Syntax and Variation: Reconciling the Biological and the Social. Edited by and Leonie Cornips and Karen P. Corrigan. Amsterdam: John Benjamins, pp. 55-80.

Sorace, Antonella. 2011. Pinning down the concept of interface in bilingualism. Linguistic Approaches to Bilingualism 1: 1-33. [CrossRef]

Sorace, Antonella, and Francesca Filiaci. 2006. Anaphora Resolution in Near-Native Speakers of Italian. Second Language Research 22: 339-68. [CrossRef]

Sportiche, Dominique. 1996. Clitic Constructions. In Phrase Structure and the Lexicon. Edited by Johan Rooryck and Laurie Zaring. Dordrecht: Kluwer Academic Publishers, pp. 213-76.

Suñer, Margarita. 1988. The Role of Agreement in Clitic-Doubled Constructions. Natural Language E Linguistic Theory 6: 391-434.

Tarrés, Mònica, and Aurora Bel. 2015. L'adquisició del català en infants portuguesos: Un estudi sobre l'ús i el coneixement dels pronoms clítics. Zeitschrift Für Katalanistik 28: 261-81.

Tarrés, Mònica, and Aurora Bel. 2017. Optionality in Sequential Bilingualism: Production of Catalan Adverbial Clitics by Children of Different L1s. Paper presented at IASCL, Lyon, France, July 17-21.

Ticio, Emma. 2015. Differential object marking in Spanish-English early bilinguals. Linguistic Approaches to Bilingualism 5: 62-90. [CrossRef]

Torrego, Esther. 1998. The Dependencies of Objects. Cambridge: MIT Press.

Trudgill, Peter. 1989. Language Contact and Simplification. Nordlyd 15: 115-21.

Uriagereka, Juan. 1995. Aspects of the Syntax of Clitic Placement in Western Romance. Linguistic Inquiry 26: 79-123.

Valenzuela, Elena. 2007. L2 Ultimate Attainment and the Syntax-Discourse Interface: The Acquisition of Topic Constructions in Non-Native Spanish and English. Ph.D. dissertation, McGill University, Montréal, QC, Canada.

(C) 2018 by the author. Licensee MDPI, Basel, Switzerland. This article is an open access article distributed under the terms and conditions of the Creative Commons Attribution (CC BY) license (http:/ / creativecommons.org/licenses/by/4.0/). 